\title{
Analysis of costs and results of treatment of rheumatoid arthritis with leflunomide and subcutaneously administered methotrexate
}

\author{
Analiza kosztów i wyników leczenia reumatoidalnego zapalenia stawów \\ leflunomidem i metotreksatem podawanym podskórnie
}

\author{
Krzysztof Kowalik², Dorota Majcherczak², Katarzyna Kolossa' ${ }^{1}$, Jerzy Krysiński², Sławomir Jeka ${ }^{1}$ \\ ${ }^{1}$ Clinical Department of Rheumatology and Connective Tissue Diseases of the Dr Jan Biziel Memorial University Hospital No. 2 \\ in Bydgoszcz \\ ${ }^{2}$ Chair of Drug Form Technology, Department of Pharmacoeconomics and Pharmaceutical Legislation, Ludwik Rydygier \\ Collegium Medicum in Bydgoszcz, Nicolaus Copernicus University in Toruń \\ ${ }^{1}$ Oddział Kliniczny Reumatologii i Układowych Chorób Tkanki Łącznej Szpitala Uniwersyteckiego nr 2 im. dr. Jana Biziela w Bydgoszczy \\ 2Pracownia Farmakoekonomiki i Ustawodawstwa Farmaceutycznego, Katedra Technologii Postaci Leku, Collegium Medicum \\ im. Ludwika Rydygiera w Bydgoszczy Uniwersytetu Mikołaja Kopernika w Toruniu
}

Key words: rheumatoid arthritis, leflunomide, methotrexate, pharmacoeconomic analysis.

Stowa kluczowe: reumatoidalne zapalenie stawów, leflunomid, metotreksat, analiza farmakoekonomiczna.

\section{Sum mary}

Aim of the study: This paper presents a retrospective analysis of costs and treatment results of patients with active rheumatoid arthritis (RA) treated with leflunomide (LEF) and subcutaneous (s.c.) methotrexate (MTX).

Material and methods: The research material was collected from the records of 111 RA patients with active RA. The patients were treated on an outpatient basis at the Clinical Department of Rheumatology and Connective Tissue Diseases Hospital University Number 2 in Bydgoszcz. The drugs were used in monotherapy. Fifty-one patients were treated with MTX s.c. and 60 with LEF p.o. This paper analyses direct medical costs of diagnostic and medical examinations, consultations, LEF and MTX s.c. purchase, as well as the purchase of support drugs, drugs used in flare of RA and drugs used to prevent and treat complications. As the European League Against Rheumatism (EULAR) guidelines suggest, the DAS28 index was used to evaluate the effectiveness of treatment. Cost-effectiveness analysis was used in the study. Results: More effective but also more expensive is the LEF treatment. The average cost of 6-month treatment of 1 patient is 2922.59 PLN, which allowed DAS28 to be reduced by $25.15 \%$. The average cost of treatment with MTX s.c. was estimated at 1582.01 PLN with the reduce of DAS28 value to $22.96 \%$. The incremental analysis shows that the cost of obtaining one additional unit of DAS28 in the course of 6 months of therapy is $26811.60 \mathrm{PLN}$ per patient. The highest share in the total cost of drugs

\section{Streszczenie}

Celem pracy była retrospektywna analiza kosztów i wyników leczenia reumatoidalnego zapalenia stawów (RZS) leflunomidem (LEF) i metotreksatem (MTX) s.c.

Materiat i metody: Dane do analizy pochodzity z dokumentacji 111 pacjentów z aktywnym RZS. Chorzy byli leczeni w warunkach ambulatoryjnych na Oddziale Klinicznym Reumatologii i Układowych Chorób Tkanki Łącznej Szpitala Uniwersyteckiego nr 2 w Bydgoszczy. Pięćdziesiąt jeden osób przyjmowało MTX s.c., a 60 - LEF p.o. Leki stosowano w monoterapii. W analizie uwzględniono bezpośrednie koszty medyczne: zakupu leków - LEF, MTX s.c., zakupu leków wspomagających, leków stosowanych w zaostrzeniach RZS, koszty zakupu leków stosowanych w zapobieganiu i leczeniu powikłań, koszty badań diagnostycznych oraz badań i konsultacji lekarskich. Zgodnie z wytycznymi EULAR do oceny skuteczności leczenia zastosowano wskaźnik DAS28. W badaniu wykorzystano analizę efektywności kosztów. Wyniki: Skuteczniejszą, ale droższą metodą leczenia jest terapia LEF. Średni koszt półrocznego leczenia jednego pacjenta wyniósł 2922,59 zt przy obniżeniu wartości DAS28 o 25,15\%. Średni koszt leczenia MTX s.c. wyniósł 1582,01 zł przy obniżeniu wartości DAS28 o 22,96\%. W analizie inkrementalnej wyliczono, że koszt uzyskania dodatkowej jednostki DAS28 w 6-miesięcznej terapii wynosi 26 811,60 zł na jednego pacjenta. Największy udział w kosztach całkowitych miał zakup leków modyfikujących przebieg choroby. Średnio na jednego pacjen-

\section{Adress for correspondence:}

prof. dr hab. n. farm. Jerzy Krysiński, Katedra Technologii Postaci Leku, CM UMK, ul. dr. A. Jurasza 2, 85-089 Bydgoszcz, tel. +48 525853788 , faks +48 5258537 88, e-mail: jerzy.krysinski@cm.umk.pl

Praca wpłynęła: 4.12.2012 r. 
purchase corresponds to disease-modifying antirheumatic drugs (DMARDs). The average cost of LEF treatment was 2276.22 PLN and for the MTX s.c. treatment was 965.03 PLN per patient. Diagnostic costs in the LEF treatment were slightly higher. The costs of medical examinations and consultations were the same in both treatments. The costs of support drugs and drugs used to prevent and treat complications are low. Conclusions: Of the two compared methods of treatment, which are considered to be the first or second-line therapies, the use of LEF is more effective but also almost twice as expensive. Considering the current price of leflunomide, it does not offer an economically attractive alternative.

\section{Introduction}

Approximately 8 to 16 thousand new cases of rheumatoid arthritis (RA) are reported every year [1], primarily in people at the height of their professional activity (30-50year-olds) [2]. Belated diagnosis and late introduction of the correct treatment can very quickly lead to disability $[3,4]$. The primary medications used to treat rheumatoid arthritis are disease-modifying drugs (DMARDs), in particular methotrexate (MTX) and leflunomide (LEF). Patients with an inadequate response to treatment or intolerance to oral MTX may receive second-line therapy in the form of LEF monotherapy or, in cases of gastrointestinal intolerance, the route of MTX administration may be changed from oral to subcutaneous.

\section{Aim of the study}

The aim of the study was to assess the effectiveness and cost of LEF and MTX s.c. therapy in patients with RA who failed to respond positively to earlier treatment or who experienced adverse effects as a result of therapy. This report provides helpful advice on choosing the better therapeutic option with regard to cost/benefit aspects and presents a breakdown of costs incurred by the payer, hospital, and patients as a result of these therapy regimens.

\section{Material and methods \\ Patients}

Materials used in this study were obtained retrospectively from the Clinical Department of Rheumatology and Connective Tissue Diseases of the Dr Jan Biziel Memorial University Hospital No. 2 in Bydgoszcz. Data for analysis were collected from the medical records of 111 patients diagnosed with RA according to 1987 ACR criteria. Patients received treatment in a therapeutic programme setting.

Patients had moderate or high disease activity (DAS28 > 3.2). All of the patients had undergone prior treatment with at least one DMARD, primarily MTX administered orally at doses of 20-25 mg/week. The reason for the change in therapy to LEF or MTX s.c. was intolerance to the pre- ta koszty LEF wynosity 2276,22 zł, natomiast koszty MTX s.c. 965,03 zł. W przypadku badań diagnostycznych nieznacznie wyższe koszty poniesiono w odniesieniu do terapii LEF. Koszty badań i konsultacji lekarskich są identyczne w obu grupach. Koszty leków wspomagających i stosowanych w leczeniu powikłań są niewielkie.

Wnioski: Z dwóch porównywanych metod leczenia, uważanych za terapie pierwszego lub drugiego rzutu, prawie dwukrotnie droższe, ale skuteczniejsze jest stosowanie LEF. Przy obowiązującej cenie LEF farmakoekonomiczna opłacalność jego stosowania była wątpliwa.

viously used medication or lack of efficacy of the therapy over a period of at least 3 months.

The group of patients treated with MTX s.c. consisted of 51 subjects: 37 females (72.55\%) and 14 males (27.45\%) aged from 33 to 75 years (mean age: 53 years). Disease duration in this group ranged from six months to 40 years (mean duration: 10 years). Subcutaneous MTX was administered in the form of an injection at doses of 20 or $25 \mathrm{mg}$ once weekly, at a rheumatological out-patient clinic. All the patients received $15 \mathrm{mg}$ of folic acid two days after MTX s.c. administration.

Subcutaneous MTX dosages were as follows:

- 11 patients received $20 \mathrm{mg}$,

- 22 patients received $25 \mathrm{mg}$,

- in 15 patients the dose was increased from 20 to $25 \mathrm{mg}$, - in 3 patients the dose was reduced from 25 to $20 \mathrm{mg}$.

The group treated with LEF consisted of 60 subjects: 53 females (88.33\%) and 7 males (11.67\%) aged from 26 to 76 years (mean age: 54 years). Patients had a disease duration of between one year and 34 years (mean duration: 13 years). Patients received treatment in an out-patient clinic setting. The medication was administered orally at a dose of $20 \mathrm{mg} /$ day $(1 \times 1$ tablet $)$.

In all of the patients, LEF and MTX s.c. were given as monotherapy. During RA exacerbations, patients from both groups took glucocorticosteroids (GCS), non-steroid antiinflammatory drugs (NSAIDs) and analgesics as needed. The study did not assess the impact of these drugs on the effectiveness of the primary medications.

\section{Study methods}

The economic analysis of the selected health programmes consisted of a cost-effectiveness analysis [5-7]. The designated point-in-time for drug prices was August 2011. The analysis was conducted in accordance with the guidelines of Good Pharmacoeconomic Practice [5-7]. The cost of prescription drugs (with the exception of MTX and LEF) was borne by the patients. The cost of purchasing MTX and LEF, diagnostic investigations and medical consultations was borne by the Polish National Health Fund (Narodowy Fundusz Zdrowia - NFZ) under the terms of its contract with the hos- 
pital. The cost of drug administration was included in the cost of medical consultations. The analysis examined treatment costs incurred over a period of 6 months from the time the patient received either MTX s.c. or LEF.

The following direct costs were included in the economic analysis: the cost of purchasing DMARDs (LEF, MTX s.c.), the cost of purchasing auxiliary drugs used in RA exacerbations (GCS, NSAIDs, and other analgesics), the cost of purchasing drugs used to prevent and treat complications, including gastrointestinal complaints, and hepatoprotective drugs, the cost of diagnostic investigations (laboratory tests and imaging studies), and the cost of medical examinations and consultations.

The DAS28 score was used to assess disease activity and the effectiveness of treatment; it was calculated based on 4 parameters: the number of tender joints, the number of swollen joints, the patient's VAS and erythrocyte sedimentation rate (ESR) (or, more rarely, CRP concentration). The number of tender and swollen joints was determined based on the "DAS28 calculation formula". Patients' VAS scores were recorded on a 100-millimetre horizontal visual analogue scale, and ESR or CRP values were obtained from attached laboratory investigation reports.

In accordance with EULAR guidelines [8], patients were divided into 3 groups depending on their response to treatment:

- good response to treatment: change in DAS28 > 1.2 points,

- moderate response to treatment: change in DAS28 > 0.6 points $\leq 1.2$ points,

- lack of therapeutic effect: change in DAS28 $\leq 0.6$ points.

The clinical effect of the treatment was assessed based on the difference between DAS28 and VAS values seen prior to treatment and after 6 months of treatment with LEF and MTX s.c. The 6-month follow-up period is, in many authors' opinion, sufficient to enable an assessment of the therapeutic effect of both medications $[9,10]$.

\section{Results}

Table I presents average disease activity parameter values before starting treatment and after 6 months of treatment.
The effectiveness of LEF therapy was assessed based on the difference in DAS28 scores and the findings were as follows:

- 35 patients (58.33\%) showed a good response to treatment (DAS28 > 1.2),

- 9 patients (15\%) had a moderate response to treatment $(0.6<$ DAS28 $<1.2)$,

Clinical
improvement
in $73.33 \%$
of patients

- 16 patients $(26.67 \%)$ showed a lack of response to treatment (DAS28<0.6).

As a result of treatment with MTX s.c.:

- 22 patients (43.14\%) had a good response to treatment (DAS28 > 1.2), $\quad$ improvement - 15 patients (29.41\%) showed a moderate response to treatment $(0.6<$ DAS28 < 1.2),

in $72.55 \%$

of patients

- 14 patients (27.45\%) had a lack of response to treatment (DAS28<0.6).

There were no differences in age or disease duration between patients who did not achieve clinical improvement, as defined by EULAR guidelines, and patients who did respond to treatment.

Table II presents the calculated costs of treatment with LEF and MTX S.C.

The largest component in the case of both therapies was the cost of DMARDs, which accounted for $77.88 \%$ of the total costs in the case of LEF and $61 \%$ of the total costs in the case of MTX s.c. The cost of treatment and prevention of complications was slightly higher in the group receiving LEF. With LEF therapy, $0.68 \%$ was spent on auxiliary drugs administered during RA exacerbations compared with $1.15 \%$ in the case of patients receiving MTX s.c. The cost of diagnostic investigations was slightly higher for LEF therapy compared with MTX s.c. $-10.54 \%$ and $18.85 \%$ of the total costs, respectively. The cost of medical examinations and consultations in both study groups was identical.

Costs of treatment incurred by patients (purchase of medications used during exacerbations, protective drugs, and medications used to treat complications) were not high and amounted to a small percentage of the total costs. In the case of patients receiving LEF, the total cost of aux-

Table I. Average values of disease activity before treatment and after 6 months of therapy

\begin{tabular}{|lcccccccc|}
\hline & \multicolumn{3}{c}{ Leflunomide } & \multicolumn{4}{c|}{ Subcutaneous methotrexate } \\
\hline Parameter & DAS28 & VAS & ESR $[\mathrm{mm} / \mathrm{h}]$ & CRP [mg/l] & DAS28 & VAS & ESR [mm/h] & CRP [mg/l] \\
\hline Before treatment & 4.89 & 64.33 & 40.60 & 15.88 & 5.14 & 62.54 & 29.31 & 15.04 \\
\hline After 6 months & 3.66 & 51.5 & 28.78 & 9.47 & 3.96 & 46.86 & 19.70 & 10.53 \\
\hline Decrease & 1.23 & 12.83 & 11.82 & 6.41 & 1.18 & 15.68 & 9.61 & 4.51 \\
\hline Percentage (\%) & 25.15 & 19.94 & 29.11 & 40.36 & 22.96 & 25.07 & 32.78 & 29.98 \\
\hline
\end{tabular}


Table II. Treatment costs of leflunomide and methotrexate s.c.

\begin{tabular}{|lcccc|}
\hline Cost component & \multicolumn{3}{c|}{ Cost (in PLN) } \\
\cline { 2 - 5 } & \multicolumn{2}{c|}{ Leflunomide** $^{\star *}$} & Subcutaneous methotrexate** \\
\cline { 2 - 5 } & total & average per patient & total & average per patient \\
\hline DMARDs & 136572.90 & 2276.22 & 49216.62 & 965.03 \\
\hline auxiliary drugs used in RA exacerbations* & 1188.32 & 19.81 & 930.73 & 18.25 \\
\hline prevention and treatment of complications* & 3791.62 & 63.19 & 2311.45 & 45.32 \\
\hline diagnostic investigations & 18491 & 308.18 & 15209 & 298.21 \\
\hline medical examinations and consultations & 15312 & 255.20 & 13015.2 & 255.20 \\
\hline total & 175355.84 & 2922.59 & 80683 & 1582.01 \\
\hline
\end{tabular}

${ }^{*}$ Costs incurred by the patient.

**Since July 2012 these drugs have been available on prescription for a lump-sum price.

iliary drugs, administered during disease exacerbations and to alleviate adverse effects, amounted to 83.00 PLN (2.84\% of the total costs), and 63.57 PLN (4.01\%) in the case of MTX s.C.

\section{Cost of therapy versus effectiveness}

The average cost per patient for 6 months of therapy with LEF was higher by 1340.58 PLN than for MTX s.c. However, after taking into account DAS28 values, LEF was seen to be the more effective drug. In such circumstances, the Guidelines on Good Pharmacoeconomic Practice (Wytyczne Dobrej Praktyki Farmakoekonomicznej) recommend conducting an incremental analysis and calculating the incremental cost-effectiveness ratio (ICER) [5-7]. ICER is calculated as the difference in costs divided by the difference in the effectiveness of comparable methods of treatment. ICER provides information on the cost of achieving an additional unit of treatment result.

CER $=\frac{2922.59-1582.01}{1.23-1.18}=\frac{1340.58}{0.05}=26811.60$ PLN/Unit DAS28

The findings of the incremental analysis reveal that the cost of achieving an additional unit of DAS 28 with 6 months of LEF therapy amounts to 26811.60 PLN per patient. Despite the fact that the difference between DAS28 scores was $0.05(1.23-1.18)$ and was not clinically significant, in view of the differences in the effectiveness of treatment using the two drugs, a decision was made to conduct the aforementioned analysis.

\section{Discussion}

The study demonstrated the effectiveness of LEF and MTX s.c. therapies in patients characterised by high dis- ease activity, resistant or refractory to earlier treatment, including oral MTX therapy. After 6 months of therapy, patients treated with LEF responded with a decrease in the DAS28 score of 1.23 (25.15\%), whereas MTX s.c. produced a decrease of 1.18 (22.96\%). The increase in the effectiveness of treatment following a change in the route of MTX administration may be the result of a difference in bioavailability (biological availability following oral administration amounts to approx. 70\%) [11]. There were no significant differences in DAS28 reduction between the two drugs, which indicates that they have similar effectiveness. Taking into consideration EULAR improvement criteria, treatment with LEF produced slightly better results than MTX S.c. Overall, $73.33 \%$ and $72.55 \%$ of patients, respectively, responded with clinical improvement (DAS28 $>0.6)$. It is worth noting, however, that a response to therapy described as good (decrease in DAS28 greater than 1.2) was reported in $58.33 \%$ of patients treated with LEF and in $43.14 \%$ of patients receiving MTX s.c., while a moderate effect (reduction in DAS28 by $0.6-1.2$ ) occurred in $15 \%$ of patients in the LEF group and $29.41 \%$ in the MTX s.c. group. A larger number of patients responded well to the introduction of a drug with a different mechanism of action than to administration of the same drug using a different route. The difference in the effectiveness of MTX therapy achieved following a change in the route of administration (by almost 23\%) is similar to the result obtained and published by Brandt et al. [12]. However, discrepancies exist with regard to the interpretation of the difference in the effectiveness of treatment with MTX administered orally and parenterally. Robbins et al. have demonstrated a comparable clinical response following oral and subcutaneous administration of MTX [13]. 
In contrast to the inconsistent data on the effectiveness of treatment with MTX S.c., earlier studies have confirmed the effectiveness of LEF therapy. Studies by RellBakalarska et al. revealed that almost $77 \%$ of patients achieve a good (reduction in DAS28 $>1.2$ in approx. 65\%) or moderate (decrease in DAS28 $>0.6$ and $<1.2$ in approx. $12 \%)$ therapeutic response [14]. According to studies by Targońska-Stępniak et al., after 6 months of treatment with $\mathrm{LEF}, 80.7 \%$ of patients were reported to have experienced clinical improvement (good response in 61.4\% and moderate response in 19.3\%) [15], while according to studies conducted by Raczkiewicz-Popierska et al., after 5 months of treatment, $54 \%$ of patients had a reduction in DAS28 $>1.2$ and approx. $30 \%$ of patients experienced a reduction in DAS28 by $0.6-1.2$ (amounting to $84 \%$ of patients in total) [16]. The effectiveness of treatment with LEF was also confirmed in a study by Balabanova et al. An assessment of LEF effectiveness based on DAS28 over 16 weeks demonstrated clinical improvement in $65 \%$ of study subjects [17], while according to studies conducted by Nguyen et al., after 6 months of LEF administration, $21.8 \%$ of patients achieved a good clinical response and $61.8 \%$ achieved a moderate clinical response (amounting to $83.6 \%$ of patients in total) [18].

Mean VAS scores in the analysed group of patients prior to the introduction of new drugs were similar: 64.33 (LEF) and 62.54 (MTX s.c.). This indicates that, irrespective of later treatment, patients' evaluation of their state of health was similar.

Both VAS and DAS28 are indicators of disease activity and although VAS is one of the components of the DAS28 score, there was no correlation between the two parameters. Comparing both groups of patients, the LEF group demonstrated a greater improvement in DAS28 compared with the MTX s.c. group. Patients' assessment of their state of health based on VAS produced a different result. The subjective nature of the VAS scale may result in such discrepancies. The remaining 3 objective parameters used to calculate the DAS28 score generally correlate with each other and were responsible for the better DAS28 results achieved with LEF.

The very fact that patients were enrolled into therapeutic programmes may have had a positive impact on subjective evaluation of the improvement in their state of health. According to some patients, participation in a drug programme implies better medical care and access to newer generations of drugs and more effective drugs, which may affect the final result of the subjective VAS score. The greater improvement in VAS in the group of patients on MTX s.C., compared with LEF (25.07\% vs. $19.94 \%)$, may be associated with the route of administration of the drug. Some patients subjectively perceive a drug to be more effective if administered in the form of an injection rather than tablets. The fact that patients must be referred to hospi- tal in order to receive medication administered by qualified medical personnel may strengthen this opinion.

This article presents the results of a cost-effectiveness analysis. Only direct medical costs incurred by the hospital and the patient were included in the analysis. The results of the analysis show that the more effective, albeit more expensive, method of treatment is LEF therapy. The average cost of 6 months of treatment per patient amounted to 2922.59 PLN and resulted in a $25.15 \%$ decrease in the DAS28 score. However, no further reduction in DAS28 should be expected with continued treatment because - according to published data - the greatest improvement may be observed during the first 6 months of treatment, following which the parameters of disease activity continue to improve, although these changes are much smaller [13]. Subcutaneous therapy, while associated with slightly poorer effectiveness of treatment, is almost half as expensive. The findings of the incremental analysis revealed that the cost of achieving an additional DAS28 unit in the course of 6 months of LEF therapy amounted to 26811.60 PLN per patient. In view of the fact that none of the patients achieved permanent remission in this period and treatment should be continued in both groups of patients, it must be assumed that the differences in costs will be even greater. In Poland, the proposed limit of cost effectiveness for treatment using comparable therapeutic programmes (ICER) amounts to $27000 \mathrm{PLN}$ per year per patient $[5,7]$. According to the calculated expenditure, LEF is costly and, from a pharmacoeconomic point of view, less cost-effective given the current price of the medication. Two alternative, registered generic leflunomide products have recently appeared on the market. This provides patients with the option to choose between the original product and its generic drugs.

The highest cost in the case of both therapies was the cost of purchasing DMARDs and this was what led to the large differences in total costs. The cost of the remaining medications purchased by patients and the cost of services provided by the hospital were similar and their impact on total costs was smaller.

Pharmacoeconomic analyses conducted in Europe (including Poland, Spain, and Germany) have shown that direct costs have a smaller share in the total cost of RA treatment (30-40\%) $[1,19,20]$. Indirect costs, resulting from lost productivity and inability to work, account for the major share of the cost of treating RA; therefore the aim of treatment, besides achieving permanent remission, should also be to maintain patients' functional capacity and professional activity for as long as possible.

It is worth noting that the presented data pertain to a 6-month period of treatment of patients participating in an NFZ programme and the prices of the analysed drugs were current prices at the time of the analysis. Drug prices 
are subject to change, which may ultimately affect the tota cost of the analysed therapy as well as the results of the incremental analysis. This does not, however, affect treatment effectiveness or cost component data, i.e. frequency of drug administration, the number of conducted diagnostic investigations, medical consultations, or the prevention and treatment of complications. Following the introduction of the Act on the Reimbursement of Drugs, Foodstuffs Intended for Particular Nutritional Purposes and Medical Devices (Ustawa o refundacji leków, środków spożywczych specjalnego przeznaczenia żywieniowego oraz wyrobów medycznych), LEF and MTX s.c. were included in the category of products available in pharmacies on prescription and, since the $1^{\text {st }}$ of July 2012, they have been available to patients for a lump-sum price.

\section{Conclusions}

1. Clinical improvement, following earlier failure of RA treatment with at least one DMARD, was reported in over $73 \%$ of patients receiving leflunomide and in over $72 \%$ of patients treated with MTX s.c.

2. The values of components that make up the total cost, with the exclusion of the cost of DMARDs, were very similar. DMARDs had a significant impact on the large difference in total costs.

3. Changes in the cost of DMARDs may significantly impact the total cost of the analysed therapies.

4. Given the price of leflunomide at the time of the analysis, its pharmacoeconomic cost-effectiveness was questionable.

5. Leflunomide is currently available at a lump-sum price. However, the decision to use LEF should take into account not only pharmacoeconomic circumstances, but also costs associated with the need for drug washout in specific clinical circumstances.

The authors declare no conflict of interest and no funding.

\section{References}

1. Ruszkowski J. Wysokie koszty gospodarcze a choroby przewlekłe. Rzeczpospolita, 3.09.2010 r.

2. Brzosko M. Reumatologia kliniczna. Wydawnictwo Pomorskiego Uniwersytetu Medycznego w Szczecinie, Szczecin 2010; 40-54, 68-78.

3. Wiland P, Madej M, Szmyrka-Kaczmarek M. Monitorowanie stanu pacjenta w chorobach reumatycznych. Górnicki Wydawnictwo Medyczne, Wrocław 2008; 1-29.

4. Zimmermann-Górska I. Reumatologia kliniczna, t. 2. Wydawnictwo Lekarskie PZWL, Warszawa 2008; 496-517.

5. Orlewska E, Nowakowska E. Farmakoekonomika dla studentów i absolwentów akademii medycznych. UM Poznań, Poznań 2004; 26-48, 121-145.
6. Orlewska E, Mierzejewski P. Polskie wytyczne przeprowadzania badań farmakoekonomicznych (projekt). Farmakoekonomika 2000; 4 (supl. 1): 2-11.

7. Orlewska E, Mierzejewski P. Project of Polish guidelines for conducting pharmacoeconomic evaluations in comparison to international health economic guidelines. Eur J Health Econ 2003; 4: 296-303.

8. Tłustochowicz W. Zalecenia EULAR dotyczące leczenia reumatoidalnego zapalenia stawów syntetycznymi i biologicznymi lekami przeciwreumatycznymi modyfikującymi przebieg choroby. Medycyna Praktyczna (wydanie specjalne) 2010; 2: 21-24.

9. Sobieska E, Sobieski B, Juzyszyn Z, Pawlik A. Wspótczesna terapia reumatoidalnego zapalenia stawów. Farm Współ 2010; 3: 97-101.

10. Zimmermann-Górska I. Reumatologia kliniczna. T. 1. Wydawnictwo Lekarskie PZWL, Warszawa 2008; 309-314.

11. Świerkot J. Podskórne iniekcje metotreksatu w leczeniu reumatoidalnego zapalenia stawów. Reumatologia 2007; 45: 407-414.

12. Brandt A. Results of an observational study with parenteral MTX. Medac GmbH, Germany 2004.

13. Robbins L, Maclary S, Ostrov B, Ferriss J. Methotrexate use in rheumatic diseases: comparison of efficacy and tolerance of oral, intramuscular and subcutaneous methods of administration. Arthritis Rheum 1997; 40: 230.

14. Rell-Bakalarska M, Jaworski J, Rutkowska-Sak L i wsp. Leflunomid $w$ terapii chorych na reumatoidalne zapalenie stawów wstępna obserwacja efektu terapeutycznego i objawów niepożądanych. Reumatologia 2006; 44: 19-25.

15. Targońska-Stępniak B, Chudzik D, Dryglewska M, Majdan M. Ocena wpływu leczenia leflunomidem na wskaźniki procesu zapalnego $u$ chorych na reumatoidalne zapalenie stawów. Reumatologia 2007; 45: 1-5.

16. Raczkiewicz-Papierska A, Dudek A, Bachta A i wsp. Leflunomid jako lek drugiego wyboru $u$ chorych na reumatoidalne zapalenie stawów. Pol Merk Lek 2007; 132: 547-550.

17. Balabanova RM, Makolkin VI, Shostak NA, et al. Changes in indices of inflammatory activity in patients with rheumatoid arthritis during early stages of basic therapy of leflunomide. Ter Arkh 2004; 76: 28-32.

18. Nguyen M, Kabir M, Ravaud P. Short-therm efficacy and safety of leflunomide in the treatment of active rheumatoid arthritis in everyday clinical use: open label, prospective study. Clin Drug Investig 2004; 24: 103-112.

19. Ruszkowski J, Leśniowska J, Gierczyński J i wsp. Koszty pośrednie i bezpośrednie leczenia reumatoidalnego zapalenia stawów w Polsce. Farmakoekonomika 2009; 13: 9.

20. Lajas C, Abasolo L, Bellajdel B, et al. Costs and predictors of costs in rheumatoid arthritis: a prevalence-based study. Arthritis Rheum 2003; 49: 64-70. 